\title{
Evaluation of Passage Route as Predictor of Outcomes of Tibial Angioplasty in Diabetic Patients
}

\author{
MOHAMED A.A. KASHKOUSH, M.Sc.*; AHMED A. TAHA, M.D.**; AHMED S. MOSTAFA, M.D.** and \\ AHMED G. FOUAD, M.D.** \\ The Department of Vascular Surgery, National Institute of Diabetes* and The Department of General \& Vascular Surgery, \\ Faculty of Medicine, Cairo University**, Egypt
}

\begin{abstract}
Background: Diabetes is one of the strongest predictors of Peripheral Arterial Disease (PAD). It is associated with two fold increase of relative risk of PAD.

Aim of Study: To evaluate passage route as predictor of outcomes of tibial angioplasty in diabetic patients.

Patients and Methods: This prospective study included 67 cases of chronic limb threatening ischemia patients (CLTI $100 \%$ ) underwentinfra genicular angioplasty. Our main interest was to determine adverse clinical events such as clinical failure, need for redo interventions and/or amputation.

Results: Almost 91\% of our cases (61/67 patients) had a positive history of hypertension that did not seem to be a significant factor of Major Adverse Clinical Outcome (MACO). Foot lesion i.e. ulcerationmay predict MACO. Intraluminal route was performed in $58(86.6 \%)$ cases and via subintimal route in 9 cases $(13.4 \%)$. In the patients operated upon via intraluminal route, twelve patients developed MACO. These results were of significant statistical value; $p$-value; 0.020 .

Conclusions: Foot lesion i.e. ulceration; the larger the wound size or the volume of tissue loss may predict MACO in addition to successful passage route either transluminal or subintimal route inbelow knee PTA is consideredpredictors of adverse outcome.
\end{abstract}

Key Words: Passage route - Predictors of outcomes - Tibial angioplasty - Diabetic arterial disease.

\section{Introduction}

CHRONIC Limb Threatening Ischemia (CLTI) is a severe form of lower limb ischemia and it is persistent, recurring rest pain needing opiate analgesia for minimum of 2 weeks duration, tissue loss of the foot or toes with ankle systolic pressure less than $50 \mathrm{mmHg}$ or toe systolic pressure less than 30 $\mathrm{mmHg}$ [1-4].

Correspondence to: Dr. Mohamed A.A. Kashkoush, The Department of Vascular Surgery, National Institute of Diabetes, Egypt
Collins et al., conducted a comprehensive study on the different imaging modalities (duplex ultrasound, MRA, and CTA) for the diagnosis of CLTI. Contrast enhanced MRA had the best overall accuracy when evaluating the arterial segment from abdominal aorta to foot [5].

Despite the advancement in the technology of arterial imaging modalities, arteriography remainsthe "gold standard" in the diagnosis of CLTI. Non contrast enhanced time of flight Magnetic Resonance Angiography (MRA) is being used in renal impairment patients [6-8].

In patients with rest pain, tissue loss and ulceration, angioplasty is now commonly regarded as the first line of therapy. Such patients have significant comorbid diseases and are at high risk from general anesthesia. Crural angioplasty has a very low associated morbidity and mortality $[\mathbf{1 , 9 , 1 0 ]}$.

Establishment of in line flow down to the foot is the goal of treatment in these patients in order to alleviate rest pain or promote healing of ulcers. Even though this initial patency may be not satisfactory, the window of improved flow frequently allows wound healing [11,12].

Because of more than $80 \%$ of patients with chronic total occlusionlesions usually need a complex technique of crossing the lesion over balloon angioplasty alone. New modalitiesusing different physical principles to cross the calcified plaque, such as blunt microdissection, or laser, have been innovated to achieve better outcomes $[\mathbf{1 3 , 1 4 ]}$.

Inspite of the dealing with chronic limb threatening ischemia (CLTI) consumes significant amount of health care resources, amputation remains a common procedure especially in diabetic patients $[15,16]$. 
The aim of this study was to evaluate passage route as predictor of outcomes of tibial angioplasty in diabetic patients.

\section{Patients and Methods}

This is a prospective study included 67 cases after informed consent with symptomatic peripheral arterial disease, either rest pain or ulcer, who underwent PTA of a below knee arterial lesions.

Diabetic patients of different age \& sex who were admitted to the Department of Vascular and Endovascular Surgery in Kasr Al-Ainy, Faculty of Medicine and National Institute of Diabetes and Endocrinology and scheduled for below knee angioplasty from the beginning of January 2013 till the end of December 2013 were included into the study. But cases who had lesions (managed in previous session) proximal to the knee, non diabeticcases or compromised renal function cases were excluded. Follow,up period was about 12 months.

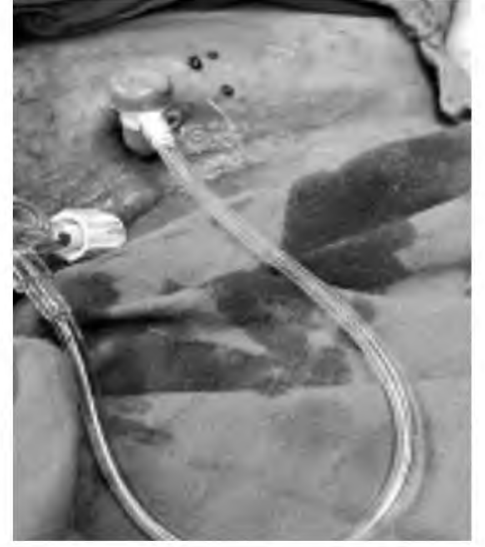

Sheath insertion

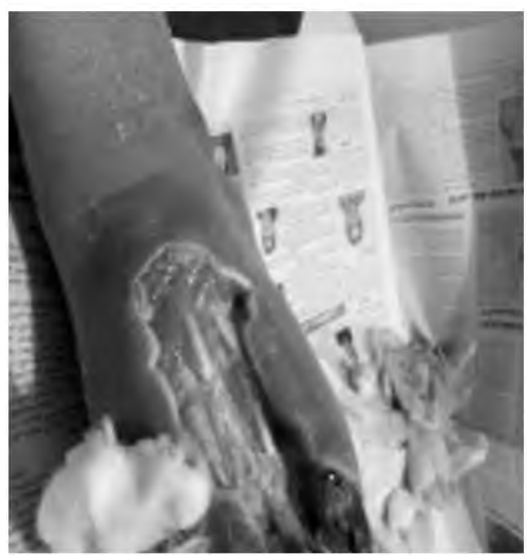

Before

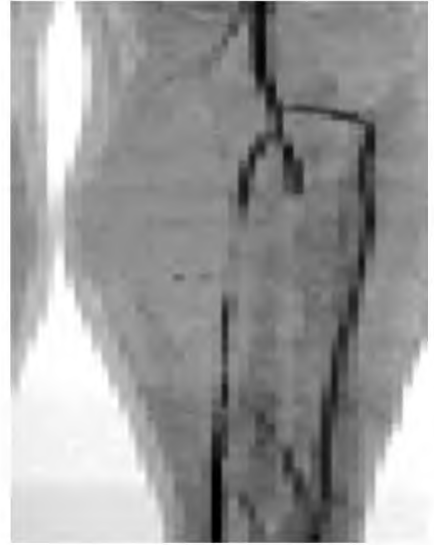

CTA pre-intervention

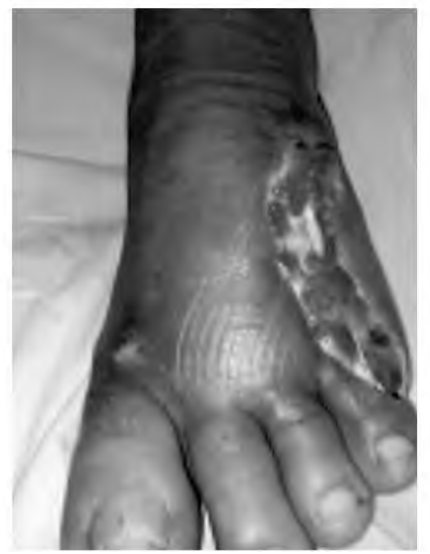

One month later
All patients had complete clinical history, physical examination, $\mathrm{ABI}$, routine and vascular laboratory. All cases had CTA performed for diagnosis and characterization of the lesions before intervention.

\section{Procedure details:}

Treated arterial lesions were located at lower popliteal, trifurcation or any of the cruralarteries. The atherosclerotic lesion was compared to that of the proximal healthy arterial segment to determine degree of stenosis, measured as a percentage.

Then ipsilateral antegrade femoral was used in about $90 \%$ of patients $(n=60)$. We performed a crossover technique using the contralateral femoral artery in seven patients $(n=7)$. We injected 5000 IU intra-arterial heparin via the sheath. The balloon diameter was determined from the diameter of adjacent non-diseased arterial segment (range 3$5 \mathrm{~mm}$ ). The balloon was inflated two to three minutes within the lesions with a mechanical inflator. Then the procedure was repeated with overlapping about $1 \mathrm{~cm}$ till dilatation of all diseased segments.

Lt. Diabetic foot debridement

Computed Tomography Angiography (CTA), Digital Subtraction Angiography (DSA)

Fig. (1): A case of tibial angioplasty followed by debridement. 
Balloon is deflated, completion angiogram was performed with the guidewire in place and procedure outcome was recorded. Subintimal angioplasty was used in small number of patients $(n=9,13 \%)$ due to lesion length and/or occlusion. The subintimal angioplasty followed Bolia's previously described techniques.

With arterial spasm, $0.1 \mathrm{mg}$ nitroglycerine was given intra-arterial bolus. After the intervention, all patients were prescribed an antiplatelet drug (clopidogrel $75 \mathrm{mg}$ daily for 3 months followed by acetylsalicylic acid $150 \mathrm{mg}$ daily thereafter). Together with lipid lowering agents (atorvastatin $40 \mathrm{mg}$ once daily) in dyslipidemic patients.

\section{Post-operative follow-up:}

Appropriate medical management was commenced, along with risk factor modification. Clinical outcomes, including improvement in rest pain and ulcer healing/resolution, were documented prior to discharge and at subsequent outpatient visits, with repeat Ankle Brachial Index (ABI) and/or Ankle Peak Systolic Velocity (APSV) performed within six weeks.

\section{Statistical analysis:}

Major Adverse Clinical Outcome (MACO) was analyzed by either descriptive: e.g. number, percentage, range, mean and Standard Deviation (SD) or analytical: Fisher's exact test or Chi-Squared $\left(\chi^{2}\right)$ for qualitative variable or $p$-value which was significant difference if $p<0.05$, non-significant difference if $p>0.05$ or highly significant difference if $p<0.001$.

\section{Results}

No mortality was reported and all cases have completed follow-up; so this prospective study included 67 cases; 42 males $(62.7 \%)$ and 25 females (37.3\%) complained rest pain or ulcer; a number of 13 patients $(19.4 \%)$ with rest pain (rutherford IV) and fifty four patients (80.6\%) had ulcer (rutherford $\mathrm{V}$ ) with a mean age of $62.25 \pm 13.56$ years old.

Almost $91 \%$ of our patients (61/67 patients) had a positive history of hypertension and were under antihypertensive treatment and the rest was normotensive (6 patients). Among the hypertensive group (14/16) $87.5 \%$ developed MACO. In the normotensive patients, two out of sixteen patients (12.5\%) developed MACO. Hypertension did not seem to be a significant factor in the development of MACO (Table 1), Fig. (2).
Table (1): Prevalence of MACO and hypertension.

\begin{tabular}{|c|c|c|c|c|c|c|c|}
\hline \multirow{2}{*}{ HTN } & \multicolumn{4}{|c|}{ Healing BKA \& Redo } & \multicolumn{2}{|c|}{ Total } & \multirow{2}{*}{$p$-value } \\
\hline & No & $\%$ & No & $\%$ & No & $\%$ & \\
\hline Yes & 47 & 92.2 & 14 & 87.5 & 61 & 91.0 & NS \\
\hline No & 4 & 7.8 & 2 & 12.5 & .5 & 9.0 & (0.569) \\
\hline
\end{tabular}

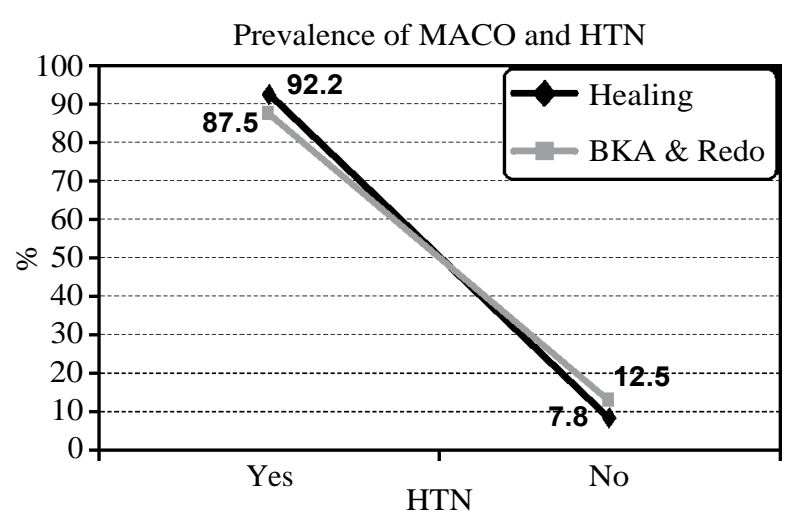

Fig. (2): Prevalence of MACO and hypertension.

Regarding the coronary or cerebral atherosclerosis, there were 26 patients with ischemic heart disease $(38.8 \%)$, five patients had ischemic heart disease and concomitant stroke $(7.5 \%)$, and 36 patients did not have any remote atherosclerosis (53.7\%). It was not a predictor of MACO as it was of no significant statistical difference. Seven patients with ischemic heart disease (7/16) 43.7\% developed MACO and 3 patients with both IHD and stroke (3/16) $18.8 \%$ developed MACO while the rest (6/16) $37.5 \%$ did not have any remote atherosclerosis (Table 2), Fig. (3).

Table (2): Prevalence of MACO and remote atherosclerosis.

\begin{tabular}{|c|c|c|c|c|c|c|}
\hline \multirow{2}{*}{$\begin{array}{l}\text { Remote } \\
\text { atherosclerosis }\end{array}$} & \multicolumn{2}{|c|}{ Healing } & \multicolumn{2}{|c|}{ BKA \& Redo } & \multirow{2}{*}{\multicolumn{2}{|c|}{$\frac{\text { Total }}{\text { No \% value }}$}} \\
\hline & $\mathrm{No}$ & $\%$ & No & $\%$ & & \\
\hline IHD & 19 & 37.3 & 7 & 43.7 & $26 \quad 38.8$ & NS \\
\hline IHD + stroke & 2 & 3.9 & 3 & 18.8 & 7.5 & (0.093) \\
\hline No & 30 & 58.8 & 6 & 37.5 & $\begin{array}{ll}36 & 53.7\end{array}$ & \\
\hline
\end{tabular}

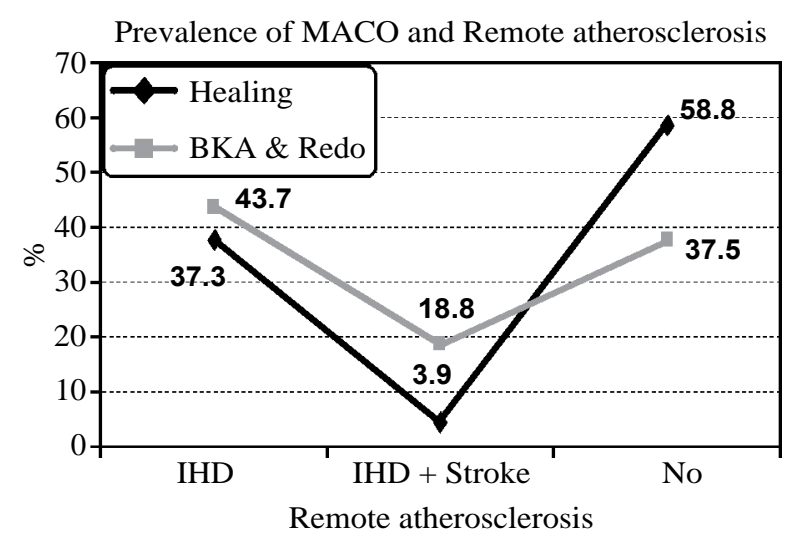

Fig. (3): Prevalence of MACO and Remote atherosclerosis. 
In our study, rest pain (rutherford IV) was the complaint in 13 cases $(19.4 \%)$. One patient underwent below knee amputation which considered MACO. These results were statistically insignificant (Table 3), Fig. (4).

Table (3): Prevalence of MACO and rest pain.

\begin{tabular}{|c|c|c|c|c|c|c|c|}
\hline \multirow{2}{*}{$\begin{array}{l}\text { Rest } \\
\text { pain }\end{array}$} & \multicolumn{2}{|c|}{ Healing } & \multicolumn{2}{|c|}{ BKA \& Redo } & \multicolumn{2}{|c|}{ Total } & \multirow{2}{*}{$p$-value } \\
\hline & No & $\%$ & No & $\%$ & No & $\%$ & \\
\hline Yes & 13 & 23.5 & 1 & 6.3 & 13 & 19.4 & NS \\
\hline No & 39 & 76.5 & 15 & 93.7 & 54 & 80.6 & $(0.252)$ \\
\hline
\end{tabular}

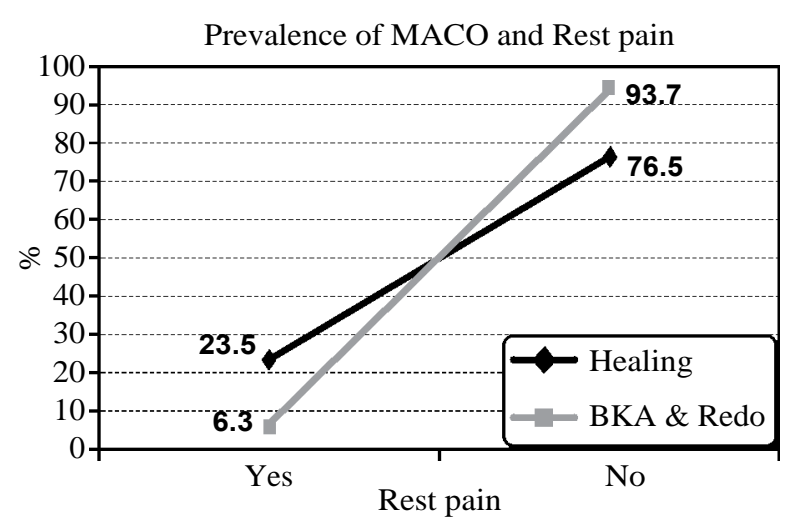

Fig. (4): Prevalenceof MACO and rest pain.

In patients treated for tissue loss; 54 cases $(80.6 \%)$. Forty one patients $(61.2 \%)$ had minor tissue loss (Rutherford V) in the form of small minute ulcer less than two $\mathrm{cm}$ in diameter and in 13 cases $(19.4 \%)$; two patients out of those thirteen cases underwent major amputation $12.5 \%$ and this was statistically significant (Table 4), Fig. (5).

Table (4): Prevalence of MACO and Ulcer.

\begin{tabular}{|c|c|c|c|c|c|c|c|}
\hline \multirow{2}{*}{ Ulcer } & \multicolumn{2}{|c|}{ Healing } & \multicolumn{2}{|c|}{ BKA \& Redo } & \multicolumn{2}{|c|}{ Total } & \multirow{2}{*}{$p$-value } \\
\hline & No & $\%$ & No & $\%$ & No & $\%$ & \\
\hline No & 40 & 78.4 & 14 & 87.5 & 54 & 80.6 & $\mathrm{~S}$ \\
\hline Toes & 11 & 21.6 & 2 & 12.5 & 13 & 19.4 & $(0.0024)$ \\
\hline
\end{tabular}

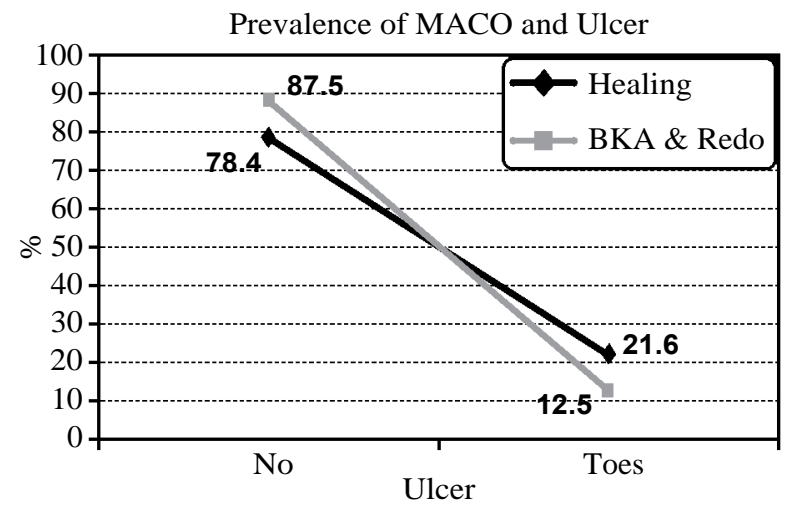

Fig. (5): Prevalence of MACO and Ulcer.
We performed angioplasty via intraluminal route in $58(86.6 \%)$ cases and via subintimal route in 9 cases $(13.4 \%)$. In the patients operated upon via intraluminal route, twelve patients developed MACO. Six patients underwent re-intervention and six patients underwent major amputation. For the group of subintimal angioplasty, four patients developed MACO. Two patients underwent reintervention and two patients underwent major amputation. These results were of significant statistical value (Table 5), Fig. (6).

Table (5): Prevalence of MACO and passage route.

\begin{tabular}{|c|c|c|c|c|c|c|c|}
\hline \multirow{2}{*}{$\begin{array}{l}\text { Passage } \\
\text { route }\end{array}$} & \multicolumn{2}{|c|}{ Healing } & \multicolumn{2}{|c|}{$\begin{array}{c}\text { BKA \& } \\
\text { Redo }\end{array}$} & \multicolumn{2}{|c|}{ Total } & \multirow{2}{*}{$p$-value } \\
\hline & No & $\%$ & No & $\%$ & No & $\%$ & \\
\hline Intra luminal & 46 & 90.2 & 12 & 75.0 & 58 & 86.6 & $\mathrm{~S}$ \\
\hline Subintimal & 5 & 9.8 & 4 & 25.0 & 9 & 13.4 & $(0.020)$ \\
\hline
\end{tabular}

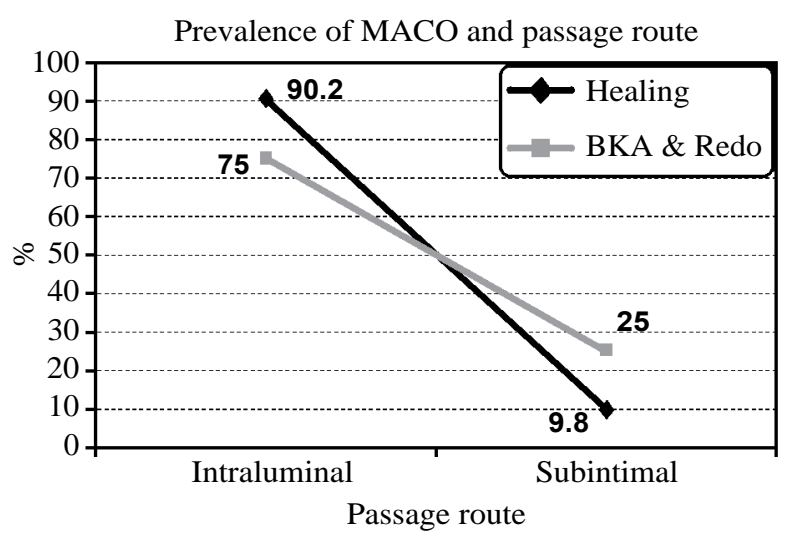

Fig. (6): Prevalence of MACO and passage route.

\section{Discussion}

Atherosclerosis is more diffuse and severe in diabetic patients with a tendency to involve below the knee (BTK) and small distal vessels. Nowadays, the multidisciplinary approach to diabetic foot, patient education, intensive wound care, and debridement in tandem with advances in technicaloptions for revascularization, especially in order to access the distal arteries, can improve the limb salvage rate $[\mathbf{1 7 , 1 8}]$.

Chronic Limb Threatening Ischemia (CLTI) is the most common cause for major amputation and indication for peripheral revascularization. The majority ofcases of CLTI are diabetic patients and CLTI in this group of patients is likely to be complicated by infected non healing ulcers [19].

Almost $91 \%$ of our patients had a positive history of hypertension and were under antihypertensive treatment. History of hyperlipidemia, cor- 
onary artery disease, and stroke was positive in $56.3,38.8$, and $7.5 \%$ of the patients, respectively, and $64 \%$ of the study population were current smokers. This was statistically insignificant and had no impact on development of MACO.

In a multicenter study by lida et al., hypertension was found in $73 \%$ and $36 \%$ of their patients were current smokers. Freedom from MALE (Major Adverse Limb Events) rate was $57 \%$ and $47 \%$ at 1 and 2 years, respectively [20].

In our study, rest pain (Rutherford IV) was the complaint in 13 cases (19.4\%). Of those only one patient had occluded tibial vessels after one year of follow-up yet he was asymptomatic and did not need any further intervention. During the followup period of one year two patients were lost for follow-up. One patient underwent below knee amputation as he had very long tibial occlusions $(8 \mathrm{~cm})$ and a diseased runoff which considered MACO. Regarding limbstatus, in Iida, et al., series of cases, 74\% (781/1057) of limbs were complicated with tissue loss and $26 \%$ of limbs were treated for rest pain [20]. Varu et al., excluded patients with rest pain (Rutherford 4) in their study [21].

The larger the wound size or the volume of tissue loss may predict MACO. However, every woundspecificationswere not available to analyze this factor in the current study. We categorized our patients as having minor or major tissue loss.

Giles et al., published their experience with infra genicular interventions for CLTI in 176 limbs. At a mean follow-up of one year, they reported complete healing or improvement in $57 \%$ of limbs, with stable wounds in $22 \%$ and worsening of the wound in $21 \%$ [22].

The subintimal angioplasty followed Bolia's previously described techniques. The statistical difference between the results of transluminal and subintimal angioplasty was significant. These results did not come in agreement with Michael et al. They stated that subintimal passage routewas performed in $12 \%(n=9)$ ofcases due to CTO lesion $(100 \%, n=9)$ and long lesionlength (mean length $=8.7 \mathrm{~cm}$, range $4-12 \mathrm{~cm}$ ). All subintimal procedureswere technically successful (100\%). Clinical failure was demonstrated in two patients, one required an aboveknee amputation and the other required a below knee amputation [23].

Subintimal plane is a technically feasible passage routefor long atherosclerotic lesions below the knee. Keeling, et al., reported a limb salvage rate of $77.8 \%$ at 3.4 year mean follow-up is equal to that previously quoted by Desgranges et al., of $78 \%$ at 24 month follow-up and compares with that of $94 \%$ at 36 months [24].

In another study by Keeling et al., amputation free survival after infra genicular subintimal angioplastywas favorable at $77.8 \%$ by the end of study period. Subintimal angioplasty was not an independent predictor of MACO [23].

\section{Conclusions:}

Foot lesion i.e. ulceration; the larger the wound size or the volume of tissue loss may predict MACO in addition to successful passage route either transluminal or subintimal route inbelow knee PTA is considered a predictors of adverse outcome.

\section{References}

1- NORGREN L., HIATT W.R., DORMANDY J.A., NEHLER M.R., HARRIS K.A. and FOWKES F.G.: TASC II Working Group. Inter-Society Consensus for the Management of Peripheral Arterial Disease (TASC II). J. Vasc. Surg., 45: S5-S67, 2007.

2- CAVANAGH P.R., LIPSKY B.A., BRADBURY A.W. and BOTEK G.: Treatment for diabetic foot ulcers. Lancet, 366: 1725-35, 2005.

3- COLLINS T.C., BEYTH R.J., NELSON D.B., et al.: Process of care and outcomes in patients with peripheral arterial disease. J. Gen. Intern. Med., 22: 942-8, 2007.

4- CONRAD M.F., CRAWFORD R.S., HACKNEY L.A., PARUCHURI V., ABULARRAGE C.J., PATEL V.I., et al.: Endovascular management of patients with critical limb ischemia: Long term results. J. Vasc. Surg., 53: 10205, 2011.

5- COLLINS R., BURCH J., CRANNY G., AGUIARIBANEZ R., CRAIG D., WRIGHT K., et al.: Duplex ultrasonography, magnetic resonance angiography, and computed tomography angiography for diagnosis and assessment of symptomatic, lower limb peripheral arterial disease: Systematic review. B.M.J., 334 (7606): 1257, 2007.

6- MELL M., et al.: Clinical utility of time-resolved imaging of contrast kinetics (TRICKS) magnetic resonance angiography for infrageniculate arterial occlusive disease. J. Vasc. Surg., 45: 543-8, 2007.

7- SCHLAGER O., et al.: Duplex sonography versus angiography for assessment of femoropopliteal arterial disease in a "realworld" setting. J. Endovasc. Ther., 14: 452-9, 2007.

8- GJONNAESS E., et al.: Gadolinium-enhanced magnetic resonance angiography, colour duplex and digital subtraction angiography of the lower limb arteries from the aorta to the tibio-peroneal trunk in patients with intermittent claudication. Eur. J. Endovasc. Surg., 31: 53-8, 2006.

9- CONRAD M.F., KANF J., CAMBRIA R.P., BREWSTER D.C., WATKINS M.T., KWOLEK C.J., et al.: Infrapopliteal angioplasty for the treatment of chronic occlusive disease. J. Vasc. Surg., Oct., 50 (4): 799-805, 2009. 
10- CONTE M.S., GERAGHTY P.J., BRADBURY A.W., HEVELONE N.D., LIPSITZ S.R., MONETA G.L., et al.: Suggested objective performance goals and clinical trial design for evaluating catheter-based treatment of critical limb ischemia. J. Vasc. Surg., 50: 1462-73, 2009.

11- COLLINS T. and McMULLAN P.W.: Percutaneous transluminal angioplasty. In: Heuser RR and Henry M, eds. Textbook of Peripheral Vascular Interventions. The United Kingdom, 2: 39-45, 2008.

12- BARGELLINI IRENE, ALBERTO PIAGGESI, ANTONIO CICORELLI, LOREDANA RIZZO, ROSA CERVELLI, ELISABETTA IACOPI, ALESSANDRO LUNARDI and ROBERTO CIONI: Predictive value of angiographic scores for the integrated management of the ischemic diabetic foot. J. Vasc. Surg., 57: 1204-12, 2013.

13- BAWEJA G. and HEUSER R.R.: Recanalization devices for chronic total occlusions (including optical coherent reflectometry). In: Heuser R.R. and Henry M., eds. Textbook of Peripheral Vascular Interventions. The United Kingdom, 2: 92-9, 2008.

14- BLANES ORTÍ P., RIERA VÁZQUEZ R., PUIGMACIÀMINGUELL R., VALVERDE GARCÍA S., MANUEL-RIMBAU MUNOZZ E. and LOZANO VILARDELL P.: Percutaneous revascularization of specific angiosome in critical limb ischemia]. Angiologia, 63 (1): 11-7, 2011.

15- ALLIE D.E., HEBERT C.J., MITRAN E.V., WALKER C.M. and PATLOLA R.R.: Critical limb ischemia. In: Heuser RR and Henry M, eds. Textbook of Peripheral Vascular Interventions. The United Kingdom, 2: 639-47, 2008.

16- ANDERSON J.L., HALPERIN J.L., ALBERT N.M., BOZKURT B., BRINDIS R.G., CURTIS L.H., DeMETS D., GUYTON R.A., HOCHMAN J.S., KOVACS R.J., OHMAN E.M., PRESSLER S.J., SELLKE F.W. and SHEN W.K.: Management of patients with peripheral artery disease (compilation of 2005 and 2011 ACCF/AHA guideline recommendations): A report of the American College of Cardiology Foundation/American Heart Association Task Force on Practice Guidelines. Circulation, 127: 1425-43, 2013.
17- DeRUBERTIS B.G., FARIES P.L., McKINSEY J.F., CHAER R.A., PIERCE M., KARWOWSKI J., et al.: Shifting paradigms in the treatment of lower extremity vascular disease: A report of 1000 percutaneous interventions. Annals of Surgery, 246: 415-24, 2007.

18- DOSLUOGLU H.H., CHERR G.S., LALL P., HARRIS L.M. and DRYJSKI M.L.: Peroneal artery-only runoff following endovascular revascularizations is effective for limb salvage in patients with tissue loss. J. Vasc. Surg., 48: 137-43, 2008.

19- UCCIOLI L., GANDINI R., GIURATO L., FABIANO S., PAMPANA E., SPALLONE V., et al.: Long-term outcomes of diabetic patients with critical limb ischemia followed in a tertiary referral diabetic foot clinic. Diabetes Care, 33: 977-82, 2010.

20- IIDA O., SOGA Y., HIRANO K., KAWASAKI D., SUZUKI K., MIYASHITA Y., et al.: Midterm outcomes and risk stratification after endovascular therapy for patients with critical limb ischemia due to isolated below-theknee lesions. Eur. J. Vasc. Endovasc. Surg., 43 (3): 31321, 2012.

21- VARU V.N., HOGG M.E. and KIBBE M.R.: Critical limb ischemia. J. Vasc. Surg., 51: 230-41, 2010.

22- GILES K.A., POMPOSELLI F.B., SPENCE T.L., HAMDAN A.D., BLATTMAN S.B., PANOSSIAN H., et al.: Infrapopliteal angioplasty for critical limb ischemia: Relation of Trans Atlantic Inter Society Concensus class to outcome in 176 limbs. J. Vasc. Surg., Jul., 48 (1): 128-36, 2008.

23- KEELING A.N., KARIM KHALIDI, SUM LEONG, TIM T. WANG, ALAA S. AYYOUB, FRANK P. McGRATH, THANOS ATHANASIOU and MICHAEL J. LEE: Below knee angioplasty in elderly patients: Predictors of major adverse clinical outcomes. European Journal of Radiology, 77: 483-9, 2011.

24- INGLE H., NASIM A., BOLIA A., et al.: Role of subintimal angioplasty of isolated infragenicular vessels in lower limb ischaemia. J. Endovasc. Therapy, 358: 68999, 2002. 


\section{تقييم طريق عبور القصور الشريانى

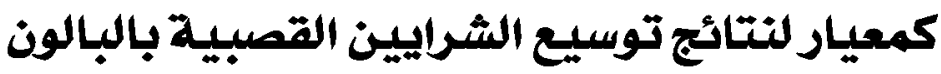

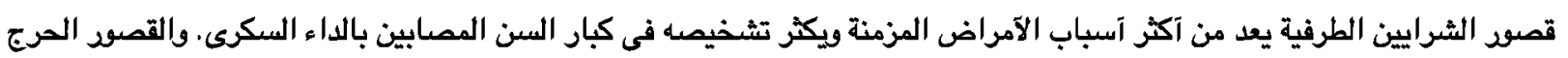
الشرايين الطرفية يعتبر مرحلة متآخرة قد تؤدى بحياة المريض آوتؤدى لبتر البتر الساق والعجز الجزئى.

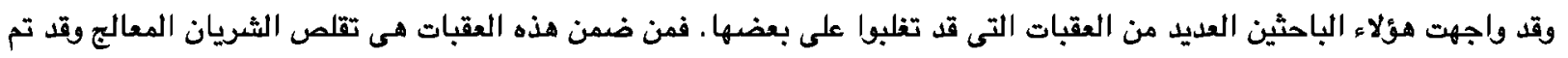

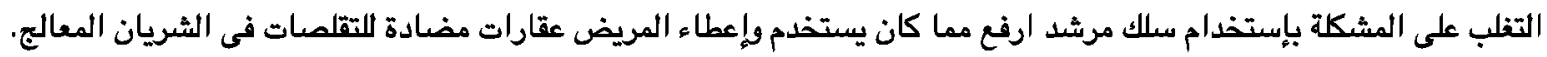
تتضمن هذه الدراسة مرضى يعانون من القصور الحرج فى الدوة الدموية للآطراف السفلية وتم علاجها بالتوسيع البالونى الشُرايين

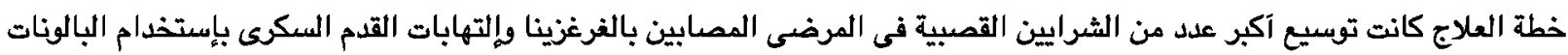

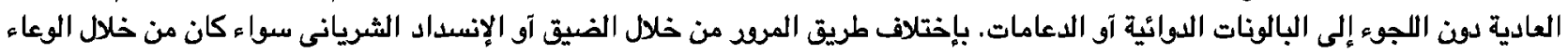
الدمعى مع سريان الدم آو غير ذلك. - الك.

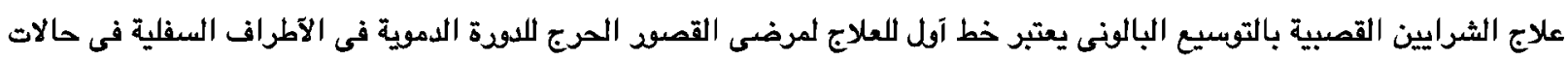

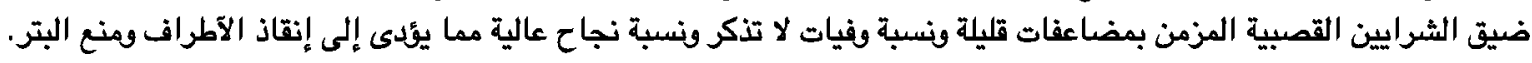

